\title{
Assessment of Effectiveness of Emergency Response Time during Landslide Event in Malaysia
}

\author{
Mohamad Fazli Sardi ${ }^{1,2^{*}}$ and Khamarrul Azahari Razak ${ }^{1,3}$ \\ ${ }^{1}$ UTM RAZAK Faculty of Technology and Informatics, Universiti Teknologi Malaysia(UTM), \\ 54100 UTM Kuala Lumpur, Malaysia \\ ${ }^{2}$ Malaysia Civil Defence Force, Prime Minister's Department, Jalan Padang Tembak, \\ 50556 Kuala Lumpur, Malaysia \\ ${ }^{3}$ Disaster Preparedness and Prevention Center, Malaysia-Japan International Institute of Technology (MJIIT), \\ University Teknologi Malaysia (UTM) 54100 UTM Kuala Lumpur, Malaysia
}

\begin{abstract}
The number of landslide disaster is increasing in Malaysia, and its impact is significant to livelihoods, socio-economic, physical and environmental assets of people and businesses. Historically, as recorded by Malaysia Public Work Department, a total of 440 landslides in Malaysia for the period 1973 to 2007, while more landslides are not properly reported and recorded. Emergency Response Planning (ERP) with right decision at the 'initial stage' of an emergency plays a major role in reducing disaster impact. Response from the rescue team was varied subjected to underlying risk, hill-slope geomorphological processes and characteristics of each landslide. Many ERP elements should be considered, e.g. data on specialised equipment and organisations must be updated. This paper provides a better insight into the effective emergency response preparedness in Malaysia. This study investigates the level of preparedness of the rescue team and the community towards landslide-prone area. Analysis of emergency response time based on the Malaysia Civil Defence Force (MCDF) experienced recorded from the classical and recent landslide in Hulu Kelang Selangor. The landslide was caused by multiple internal and external factors, which mainly induced by inadequate design of retaining structures and slopes. So far, 28 historical landslide events were reported in the Hulu Kelang area from 1990 to 2011 with 21 cases of them were triggered by rainfall. The results are promising concerning emergency response time and its effectiveness. This study also addresses the issues and challenges of disaster preparedness and awareness carried out by relevant stakeholders especially in the context of landslide emergency response. Several best practices of the effective emergency response are critically reviewed and presented. As a conclusion, this study shows that an effective emergency response preparedness is crucial for supporting an effective early warning system coupled to enhanced public awareness and preparedness with structured training programs.
\end{abstract}

Keywords: landslide; response time; ERT; emergency; Malaysia Civil Defence Force

\section{INTRODUCTION}

The rapid development of the urban area has increased the exposure and vulnerability of the people and assets. It also made the appropriate slope failure preventive measures are challenging, despite all technological advancement and cost-effective methods. Landslides and slope failures remained the fatal disasters in Malaysia, with highest recorded number of fatalities due to the Tropical Storm Grey in 1996. One of progressively developed

*Corresponding author's e-mail: jalin.sardi@gmail.com 
hillslope areas is Hulu Kelang (or also known as Ulu Klang). It is a state constituency in Gombak district in Selangor and known with its landslide occurrences in the past (Sew and Chin, 2006; Faisal, 2000; Huat et al., 2012; Lee et al., 2014; Saadatkhah et al., 2015). The area was subjected to a total of reported 28 historical landslides from 1990 to 2011; with 21 cases of them were identified as potentially triggered by intense rainfall. This study is in-line with the Priority 4 of Sendai Framework for Disaster Risk Reduction 2015-2030 on the enhancement of the preparedness for the effective response, and also the National Slope Master Plan 2017-2023 (Revised in 2016) (PWD, 2017; Jaapar, 2006).

\section{STUDY AREAS}

\section{A. Historical Records and Landslide Parameters}

Based on the data sources from the Majlis Perbandaran Ampang Jaya (MPAJ), the Slope Engineering Branch, Public Work Department (PWD), and previous studies by (Lee et al., 2014; Samah, 2007; Mariappan et al., 2011), a total of 28 historical landslides were reported in the Hulu Kelang area from 1990 to 2011. About 21 cases were identified as potentially triggered by rainfall. Figure 1 shows the specific locations of these rainfall-induced landslides. They were generally scattered all over the developed parts of the Hulu Kelang area implying hillside development has caused disturbance to the ecosystem, and hence the stability of the natural slopes.

Based on the rainfall data from Department of Irrigation and Drainage and Malaysian Meteorology Malaysia in the past 22 years (from 1990 to 2011), Hulu Kelang area received an average annual rainfall of about $2,440 \mathrm{~mm}$. The rainfall distributions in Malaysia are characterised by two monsoon seasons, namely the Southwest Monsoon from late May to September and the Northeast Monsoon from November to March. However, the highest rainfall normally occurs during the transition period between the monsoon seasons or known as the inter-monsoon season (METMalaysia, 2017). Normally, April and May receive the highest rainfall amount and followed by October and November. January is normally the driest month throughout a year (Desa and Niemczynowicz, 1996). However, this pattern is subjected to changes in climate and extreme events.
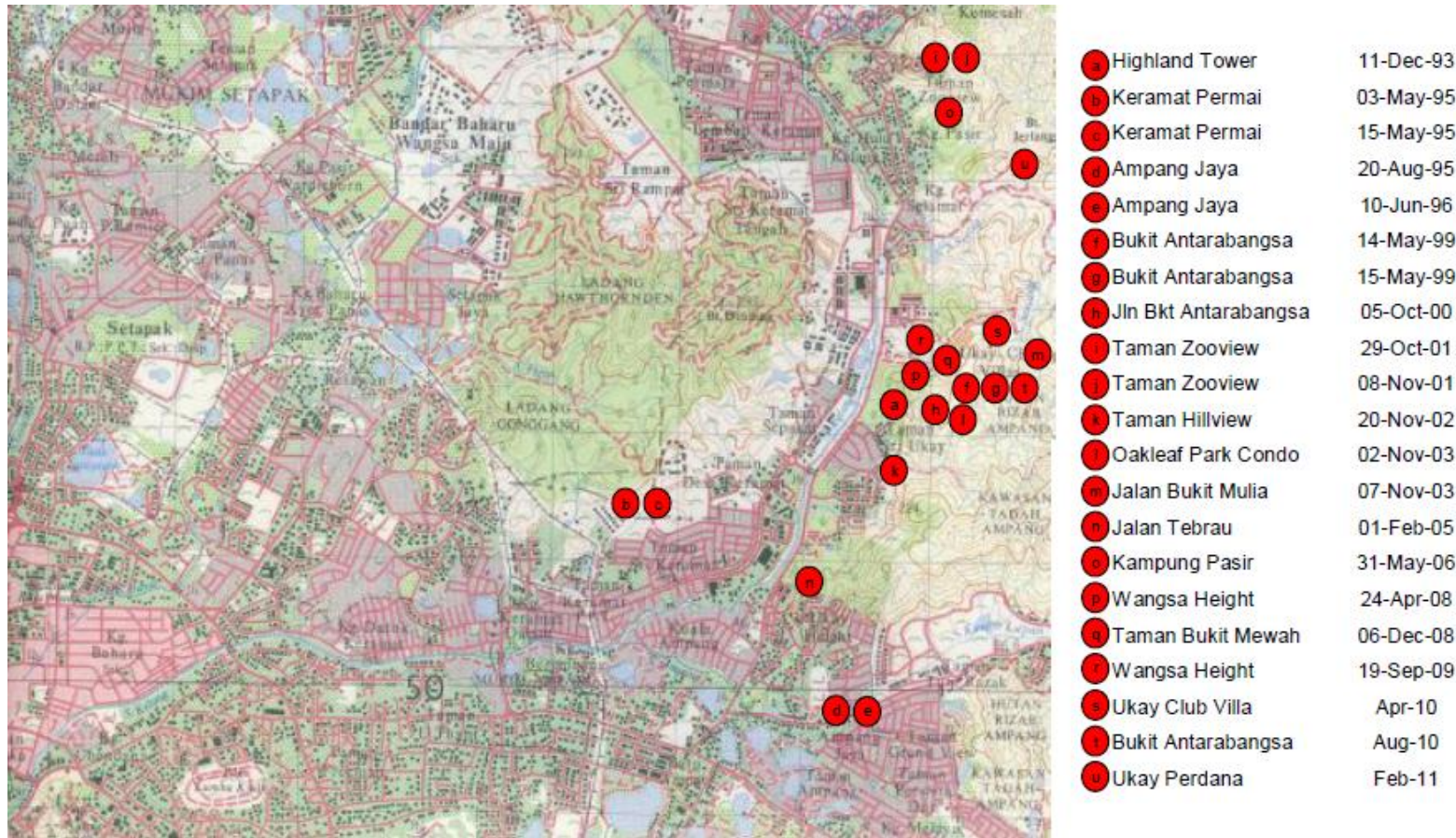

Figure 1. Specific Locations of the 21 Historical Rainfall-induced Landslides in Hulu Kelang Area from 1990 to 2011 (Map KL-PJ Series L7O3o, Edition 1-PPNM, Sheet 3757) 
Figure 2 summarises the month of occurrences of the 21 landslide events in Hulu Kelang area from 1990 to 2011. The landslide occurrences showed good agreements with the rainfall characteristics as discussed earlier. Over $60 \%$ of the landslides occurred within April, May, October, and
November, while no landslide has been reported in January. These observations signified the importance of correlating the initiations of landslide occurrences in Hulu Kelang area with rainfall infiltrations.

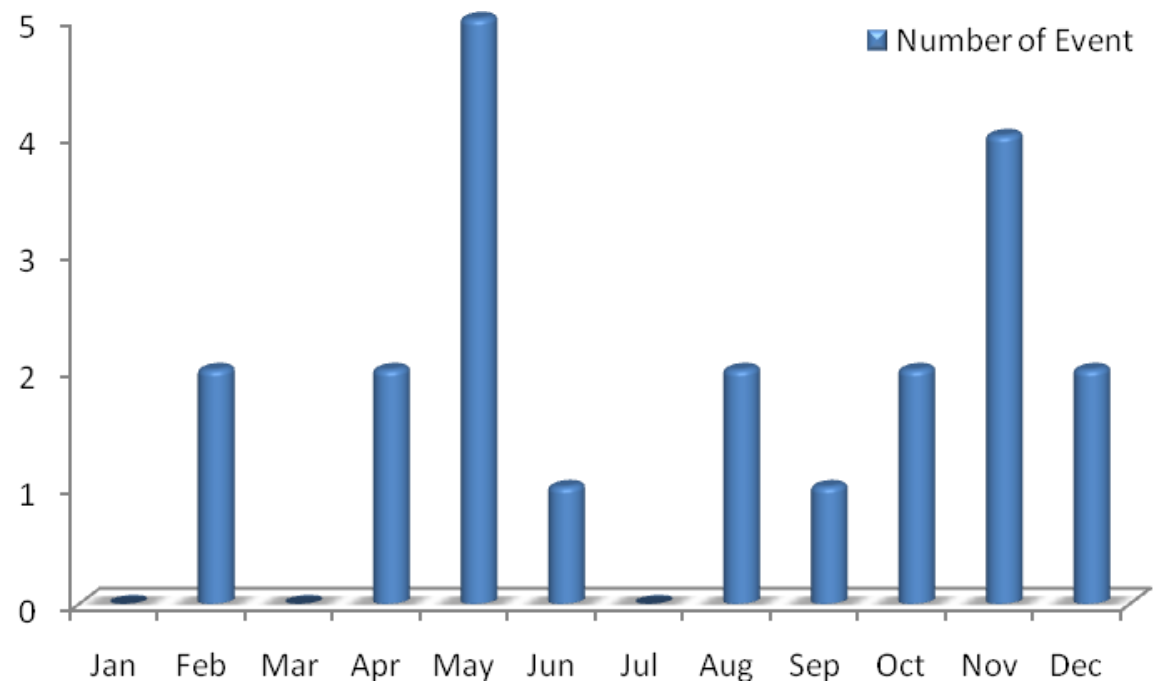

Figure 2. Landslide Occurrence in Hulu Kelang Area Between 1990 to 2011

In this study, we used two case studies in Malaysia, namely:-

1. Classical Incident - Highland Tower, Taman Hillparks, Hulu Klang, Selangor in 1993

Highland Towers tragedy was involving one of the three blocks of condominiums in Taman Hillview, Hulu Klang, Selangor, on 11 December 1993. Highland Towers was a three-block condominium with 12 levels called Blocks One, Two and Three. It was the first and the worst since Malaysia's independence, with about 48 people dead and two injured.

MCDF Dang Wangi District Operations Control Center (DOCC) had received an emergency call at 1:40 $\mathrm{pm}$ and had activated a rescue team to the scene with staff strength of six peoples. When they arrived at the scene, a chaotic situation observed and the Fire \& Rescue Department's personal have also arrived at the scene. In the early stages of the operation, limited effort of search and rescue (SAR) work can be done as the number of victims trapped under the rubble was unknown. Besides that, this was the first experience for the rescue team facing such a situation, without having the know-how in the disaster emergency and limited SAR equipment.

Emergency calls were received by the MCDF Control Center for Malaysia Emergency Response System (MERS), 999, about the landslide, occurred in Bukit Antarabangsa. A rescue team from DOCC Dang Wangi, consisting eight members rushed to the scene for the initial survey and rescue operation. Rescue work was assisted by MCDF Special Forces (Pasukan Khas Pertahanan Awam, PASPA) who has expertise in various areas such as landslide's rescue operation. Additional assistance in terms of workforce and equipment as well as the close cooperation of various agencies, allow salvage work done more quickly and efficiently. 


\section{Latest Incident - Taman Bukit Utama \&}

Taman Bukit Mewah, Bukit Antarabangsa,

Hulu Klang, Selangor in 2008

2008's Bukit Antarabangsa landslide happened on December 6. Four people were killed and 15 others injured in addition to 14 bungalows destroyed in the landslide in Taman Bukit Mewah and Taman Bukit Utama at 3:50 am. The event took place about 1.5 miles from the Highland Towers tragedy on December 11, 1993.

\section{METHODS}

\section{A. Malaysia Civil Defence Department (MCDF) Experiences}

Malaysia Civil Defence Department (MCDF) has enhanced their system operation based on the disaster management work carried out with efficiently, effectively and in accordance with the procedures as outlined by Civil Defence Standard Operating Procedures (SOP). The purpose of the SOP is to serve as guidelines to the officers and members of the MCDF in pursuing a common work process of other agencies involved in emergency and disaster management in the country. This SOP is used in duties include handling of the disaster and emergency at the Federal, State and District level. The task operation covers disasters and emergencies such as landslides, building collapses, flooding, open fires, coastal rescue, emergency medical services, terrorism, riots and other forms of action, which shall be taken by the rescue and emergency responders.

A series of past tragedy and landslide reports lead to the investigation to enhance the effectiveness of Civil Defence SOP which designed to meet the actual operating situation. It is also to improve our quality of services during disaster operations, particularly landslides. Besides, some collective perceptions on readiness and preparedness of particular respondents were observed and analysed. This analysis helps in enhancing and enriching the quality of service delivery both in terms of Civil Defence training or operations.

Review or analysis of high-risk areas to landslides should be carried out by the authorities. It allows preventive, and early preparation can be taken by the department or agency related to such local authority. In addition, the public should able to know in advance the risks faced and take necessary actions. Besides that, the rescue team can improve their response time in the event of landslides. The reaction is an immediate action taken by the department or agency managing disaster rescue such as:

- Search and rescue / evacuation;

- Emergency medical services and health;

- Preparation of evacuation centres;

- Provision of food; and

- Rehabilitation/provision of water, electricity and other basic amenities.

Nowadays, MCDF is facing more challenges due to complexity disaster or emergency incidents. Therefore, emergency administrators seek appropriate methods to enhance system performance. One component scrutinised is the response time (RT) interval between call recipients and arrival on scene. While reducing RTs may improve survival, this remains speculative and unreported (Blackwell and Kaufman, 2002). A critical factor in the effectiveness of any emergency response agency is the ability of the personnel and equipment mobilises to the scene of the emergency promptly (Basu et al., 2017).

This response time can be roughly divided into two broad components: mobilisation time and travel time (Swaroop et al., 2013). The push to reduce response times is predicated on the widely-held belief that faster responses will improve health outcomes. The response time is a 
commonly-used measure of Emergency Medical Service (EMS) quality (Bailey and Sweeney, 2003; Tijssen et al., 2015; Wilde, 2013). The National Fire Protection Association (NFPA) recommended, at least 90 per cent of EMS calls, Basic Life Support (BLS) services should reach the scene of a medical incident within four minutes (McCoy et al., 2013).

The performance of MCDF Emergency Response Time (ERT) is measured by the achievement of Key Performance Index (KPI) (Sardi, 2012). In 2011, KPI of ERT set to 100\%: 'reached the scene, not more than 10 minutes for a distance of 10 kilometres from the Malaysia Emergency Response System (MERS) 999
Operations Control Center (OCC)' (JPAM, 2012). The statistics obtained in 2011 found that the performance obtained is at the level of $63 \%$ which failed to reach the target of $100 \%$ (Figure 3). A high KPI of ERT resulted in high disagreement for poor performance. The department was later set a new KPI, to 30 minutes for ERT (JPAM, 2013). This option is based on the observation of random achievements from the previous year. The statistics in 2012 indicated a significant increase in the achievement of KPI ERT up to $87 \%$, but it is still not $100 \%$ achieved. Despite the reduction action for KPI ERT in 2012, it does not reflect the reasonable results and better achievement.

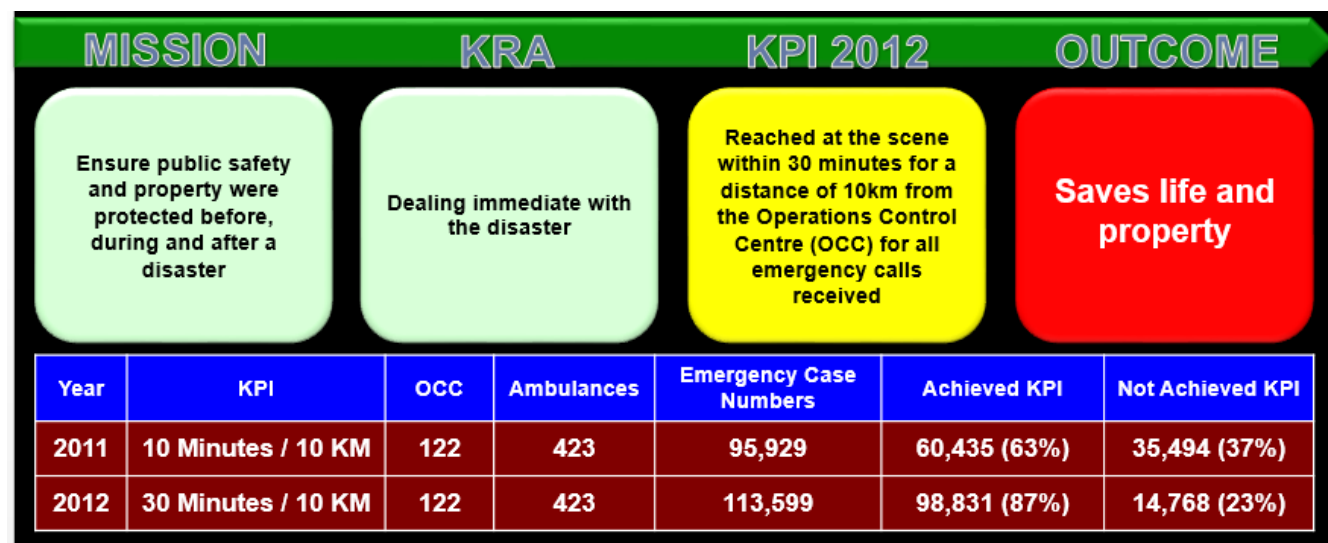

Figure 3. MCDF KPI’s Achievement on Emergency Response Time (2011-2012)

Based on the MCDF's record for Hulu Klang area, a total of 32 cases of landslides was successfully addressed from 1990 to 2013. Every case of landslide disaster has its characteristics to be faced by rescue teams to save lives and property. It has also matured MCDF in terms of improving the quality of service delivery operations with the addition of assets and logistics and has many competent members. Besides that, continuous training and awareness program among the people, especially who are involved directly with this kind of disaster were seriously main focus of MCDF to let them be a first responder during the incident. MCDF outline some kind of training for public, especially those exposed directly to the risk of landslides such as community based disaster and emergency training, first aid training, evacuation drills and many other types of training given to provide awareness to the public and also know the early warning sign due to the event (JPAM, 2014).

This case study was carried out to compare two landslides incident in the Hulu Klang. The comparison was taken two samples of landslide event between classical and the latest, analyse the effectiveness of the emergency response time by the MCDF. The samples are, (i) classical incident: Highland Tower - December 11, 1993; and (ii) latest incident: Bukit Antarabangsa, December 6, 2008. These two samples were selected based on 
their unique variables that have similarities such season. Table 1 shows the landslide overview of as geographical area, rainfall and monsoon this Hulu Kelang study cases.

Table 1. An Overview of Landslides in Hulu Kelang Compiled by MCDF

\begin{tabular}{|c|c|c|c|}
\hline \multirow{2}{*}{ No. } & \multirow{2}{*}{ Subjects } & \multicolumn{2}{|c|}{ Landslide Events } \\
\hline & & Highland Tower & Bukit Antarabangsa \\
\hline 1 & Date & December 11, 1993 & December 6, 2008 \\
\hline 2 & Time & $1330 \mathrm{OH}$ & $\mathrm{O} 35 \mathrm{OH}$ \\
\hline \multirow{5}{*}{3} & \multicolumn{3}{|l|}{ Casualties } \\
\hline & - $\quad$ Death & 48 & 4 \\
\hline & - Injured & 2 & 15 \\
\hline & - $\quad$ Saved & - & 93 \\
\hline & - $\quad$ transferred & 2,000 & $3,000-5,000$ \\
\hline 4 & Destroyed & 1 Block A Condominium & 14 bungalows \\
\hline 5 & Affected Area & Taman Hillview & $\begin{array}{l}\text { Taman Bukit Utama \& } \\
\text { Taman Bukit Mewah }\end{array}$ \\
\hline 6 & $\begin{array}{l}\text { Rescue Team } \\
\text { Members }\end{array}$ & $\begin{array}{ll}\text { a. } & \text { Malaysia: from several } \\
& \text { agencies including MCDF } \\
& (111 \text { members) } \\
\text { b. International: from UK, } & \text { US, Japan, France etc. }\end{array}$ & $\begin{array}{l}\text { From several agencies including } \\
\text { MCDF ( } 137 \text { members) }\end{array}$ \\
\hline 7 & $\begin{array}{l}\text { Logistics / } \\
\text { Equipments }\end{array}$ & $\begin{array}{ll}\text { a. } & \text { Malaysia: } \\
- & \text { TUDM - helicopters } \\
& \text { (Nuri \& Elluatte); } \\
\text { - } & \text { Used bulldozer, concrete } \\
& \text { crushing machine; } \\
\text { - } & \text { MCDF (2 x RQ Tender; } 4 \\
& \text { x Lorry Trucks; } 2 \text { x } \\
& \text { Ambulance; } 2 \text { x LRV. } \\
\text { b. } & \text { International: } \\
\text { - } & \text { France (K9 unit, Delsar) } \\
- & \text { Singapore (USAR Team) } \\
- & \text { Japan (Hi-tech } \\
& \text { equipments). Etc. }\end{array}$ & $\begin{array}{l}\text { ATM - } 4 \text { lanes tactical bridges; } \\
\begin{aligned} \text { MCDF } & \\
- & 2 \times \text { RQ Tender; } \\
- & 4 \times \text { Lorry Trucks; } \\
- & 4 \times \text { Ambulance; } \\
- & 5 \times \text { LRV; } \\
- & \text { Fiber Optic Camera; } \\
- & \text { Delsar; } \\
- & \text { Shovel \& hoe; } \\
- & \text { Jack \& air lifting bag; }\end{aligned} \\
\text { Etc. }\end{array}$ \\
\hline 8 & Rainfall & $\begin{array}{l}10 \text { days prolonged raining before } \\
\text { the event }\end{array}$ & $\begin{array}{l}14 \text { days of prolonged rainfall } \\
\text { before the event }\end{array}$ \\
\hline 9 & Slope & Scale $3 \& 4$ & Friction angle $23 \varphi$ \\
\hline 10 & Soil & $\begin{array}{l}\text { Sand mixed soil, mosses and soil } \\
\text { sediment }\end{array}$ & $\begin{array}{l}\text { Granitic rocks, Mosses and soil } \\
\text { sediment }\end{array}$ \\
\hline 11 & $\begin{array}{l}\text { Incident Indicator } \\
\text { (Incubation Period) }\end{array}$ & $\begin{array}{l}\text { Retaining wall crack - } 1 \text { month } \\
\text { before; }\end{array}$ & Soil movement \\
\hline
\end{tabular}




\section{RESULTS AND ANALYSIS}

Table 2 summarised the MCDF resources deployment in the emergency response to the landslide events for two case studies. The percentage of personnel and equipment based on the maximum number of MCDF personnel's and equipment deployed is given in Figure 4.

Table 2. Summary of Chronology of MCDF Emergency Response to the Landslide Case Studies

\begin{tabular}{|c|c|c|c|c|c|c|c|c|c|}
\hline \multicolumn{2}{|c|}{ Day (D) } & \multicolumn{2}{|c|}{ Human Resources (HR) } & \multicolumn{2}{|c|}{ Equipment (E) } & \multicolumn{4}{|c|}{ Summary } \\
\hline $\mathbf{D}_{1}$ & $\mathbf{D}_{2}$ & $\mathbf{H R}_{\mathbf{1}}$ & $\mathbf{H R}_{2}$ & $\mathbf{E}_{\mathbf{1}}$ & $\mathbf{E}_{2}$ & $\begin{array}{c}\sum \text { HR }_{1} \\
(\%)\end{array}$ & $\begin{array}{l}\sum \mathbf{E}_{1} \\
(\%)\end{array}$ & $\begin{array}{c}\sum \mathrm{HR}_{2} \\
(\%)\end{array}$ & $\begin{array}{l}\sum \mathrm{E}_{2} \\
(\%)\end{array}$ \\
\hline \multirow[t]{5}{*}{$\begin{array}{l}1 \\
\text { (Dec 11, } \\
\text { 1993) }\end{array}$} & \multirow[t]{5}{*}{$\begin{array}{l}1 \\
\text { (Dec } \\
6, \\
2008)\end{array}$} & $\begin{array}{l}\text { 1340 First Rescue } \\
\text { Team arrived ( } 6 \\
\text { members) from Dang } \\
\text { Wangi }\end{array}$ & $\begin{array}{l}\text { O405 First Rescue Team } \\
\text { and Ambulance Team } \\
\text { arrived ( } 8 \text { members) } \\
\text { from Dang Wangi }\end{array}$ & $\begin{array}{l}\text { RQ Tender } \\
\text { (1 no) }\end{array}$ & $\begin{array}{l}\text { RQ Tender } \\
\text { (1 no); } \\
\text { Ambulance } \\
\text { (1 no) }\end{array}$ & $\begin{array}{l}6 \\
(5)\end{array}$ & $\begin{array}{l}1 \\
(10)\end{array}$ & $\begin{array}{l}8 \\
(6)\end{array}$ & $\begin{array}{l}2 \\
(13)\end{array}$ \\
\hline & & $\begin{array}{l}\text { 1410 Medical team } \\
\text { from Dang Wangi } \\
\text { arrived ( } 4 \text { members) }\end{array}$ & $\begin{array}{l}\text { O420 Rescue Team from } \\
\text { Ampang arrived ( } 4 \\
\text { members) and PASPA } \\
\text { (12 members) }\end{array}$ & $\begin{array}{l}\text { Ambulance } \\
\text { (1 no) }\end{array}$ & $\begin{array}{l}\text { LRV } \\
\text { (1 nos); } \\
\text { Van (1 no) }\end{array}$ & $\begin{array}{l}10 \\
(9)\end{array}$ & $\begin{array}{l}2 \\
(20)\end{array}$ & $\begin{array}{l}24 \\
(18)\end{array}$ & $\begin{array}{l}4 \\
(27)\end{array}$ \\
\hline & & $\begin{array}{l}\text { 15OO Assembly of } \\
\text { MCDF members from } \\
\text { Dang Wangi and } \\
\text { Ampang ( } 34 \\
\text { members) }\end{array}$ & $\begin{array}{l}\text { O510 Medical Team from } \\
\text { Ampang arrived ( } 4 \\
\text { members) }\end{array}$ & $\begin{array}{l}\text { Lorry Trucks } \\
\text { (2 nos); } \\
\text { Ambulance } \\
\text { (1 no) }\end{array}$ & $\begin{array}{l}\text { Ambulance } \\
\text { (1 no) }\end{array}$ & $\begin{array}{l}44 \\
(40)\end{array}$ & $\begin{array}{l}5 \\
(50)\end{array}$ & $\begin{array}{l}28 \\
(20)\end{array}$ & $\begin{array}{l}5 \\
(33)\end{array}$ \\
\hline & & $\begin{array}{l}1630 \text { Found victims - } \\
2 \text { adult \& } 1 \text { baby }\end{array}$ & $\begin{array}{l}\text { O730 Assembly of MCDF } \\
\text { members from Dang } \\
\text { Wangi and Ampang ( } 28 \\
\text { members) }\end{array}$ & - & $\begin{array}{l}\text { Lorry } \\
\text { Trucks } \\
\text { (1 no); } \\
\text { LRV (1 no) }\end{array}$ & - & - & $\begin{array}{l}56 \\
(41)\end{array}$ & $\begin{array}{l}7 \\
(47)\end{array}$ \\
\hline & & $\begin{array}{l}\text { 2000 SAR activities } \\
\text { were suspended }\end{array}$ & $\begin{array}{l}\text { o900 Assembly of MCDF } \\
\text { members from Batu ( } 18\end{array}$ & - & $\begin{array}{l}\text { Lorry Truck } \\
\text { (2 nos); }\end{array}$ & - & - & $\begin{array}{l}127 \\
(93)\end{array}$ & $\begin{array}{l}12 \\
(80)\end{array}$ \\
\hline
\end{tabular}




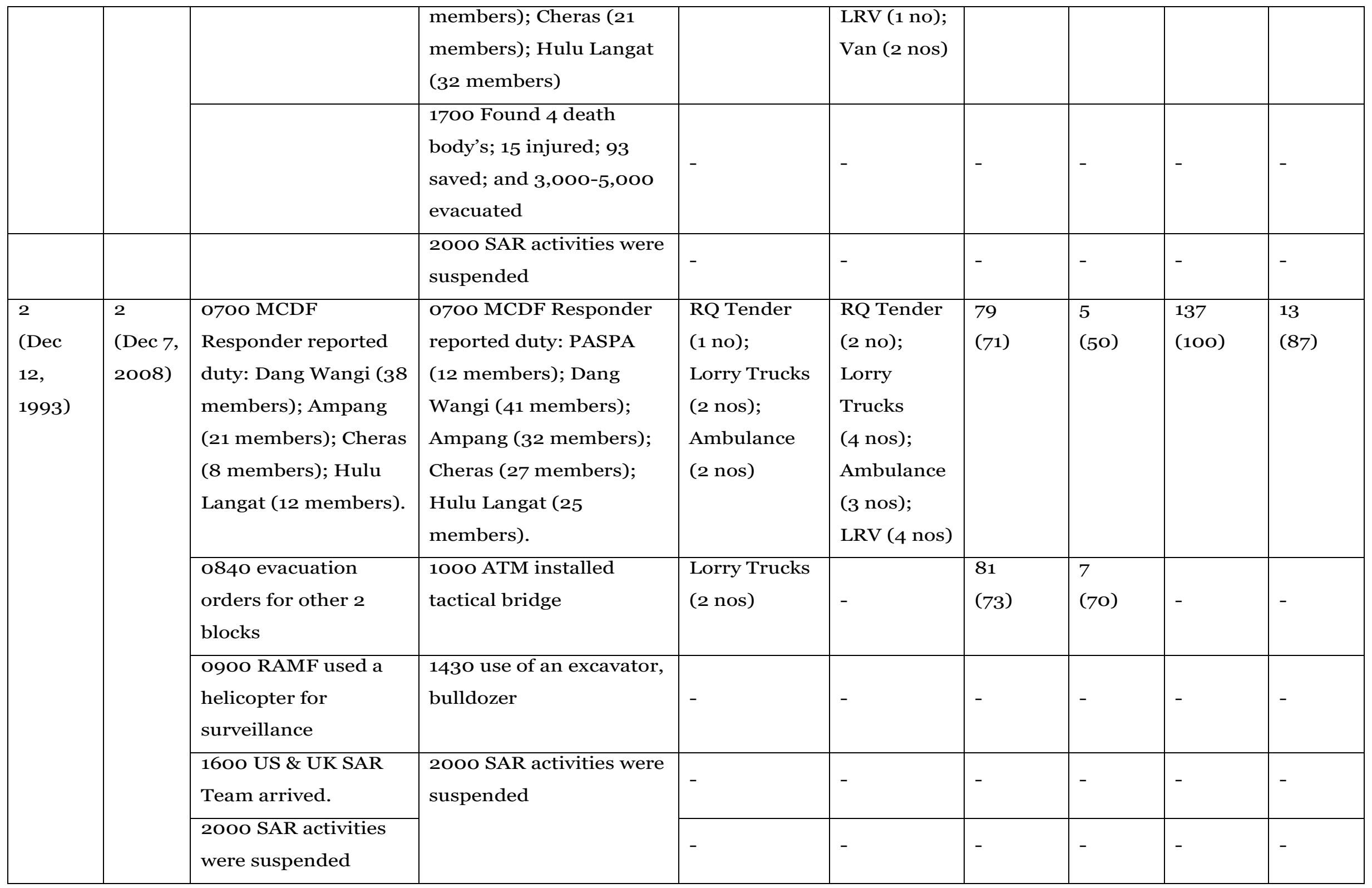




\begin{tabular}{|c|c|c|c|c|c|c|c|c|c|}
\hline \multirow[t]{4}{*}{$\begin{array}{l}3 \\
(\mathrm{Dec} \\
13, \\
1993)\end{array}$} & \multirow[t]{3}{*}{$\begin{array}{l}3 \\
\text { (Dec } \\
8, \\
2008)\end{array}$} & $\begin{array}{l}\text { O700 MCDF } \\
\text { Responder reported } \\
\text { duty: Dang Wangi (41 } \\
\text { members); Ampang } \\
\text { (28 members); } \\
\text { Cheras (15 members); } \\
\text { Hulu Langat ( } 27 \\
\text { members); }\end{array}$ & $\begin{array}{l}\text { O7O0 MCDF Responder } \\
\text { reported duty: PASPA } \\
\text { (16 members); Dang } \\
\text { Wangi (48 members); } \\
\text { Ampang ( } 26 \text { members); } \\
\text { Cheras ( } 25 \text { members); } \\
\text { Hulu Langat ( } 18 \\
\text { members). }\end{array}$ & $\begin{array}{l}\text { RQ Tender } \\
\text { ( } 2 \text { no); } \\
\text { Lorry Trucks } \\
\text { (4 nos); } \\
\text { Ambulance } \\
\text { (2 nos) }\end{array}$ & $\begin{array}{l}\text { RQ Tender } \\
\text { (2 no); } \\
\text { Lorry } \\
\text { Trucks } \\
\text { (4 nos); } \\
\text { Ambulance } \\
\text { (4 nos); } \\
\text { LRV (5 nos) }\end{array}$ & $\begin{array}{l}111 \\
(100)\end{array}$ & $\begin{array}{l}8 \\
(80)\end{array}$ & $\begin{array}{l}133 \\
(97)\end{array}$ & $\begin{array}{l}15 \\
(100)\end{array}$ \\
\hline & & $\begin{array}{l}\text { o80o France SAR } \\
\text { Team arrived with K9 } \\
\text { Units and Delsar. }\end{array}$ & 1400 Found a dead dog & - & - & - & - & - & - \\
\hline & & $\begin{array}{l}\text { 200O SAR activities } \\
\text { were suspended }\end{array}$ & $\begin{array}{l}\text { 1600 SAR operation were } \\
\text { stop, but document } \\
\text { search continues. }\end{array}$ & - & - & - & - & - & - \\
\hline & & & $\begin{array}{l}1630 \text { Tactical bridge } \\
\text { completion; and } \\
\text { electricity recovered }\end{array}$ & - & - & - & - & - & - \\
\hline \multirow[t]{2}{*}{$\begin{array}{l}4 \\
(\mathrm{Dec} \\
14, \\
1993)\end{array}$} & \multirow[t]{2}{*}{$\begin{array}{l}4 \\
(\mathrm{Dec} \\
9, \\
2014)\end{array}$} & $\begin{array}{l}\text { O7OO MCDF } \\
\text { Responder reported } \\
\text { duty: Dang Wangi (38 } \\
\text { members); Ampang } \\
\text { (24 members); } \\
\text { Cheras (18 members); } \\
\text { Hulu Langat ( } 21 \\
\text { members); }\end{array}$ & $\begin{array}{l}\text { O700 MCDF Responder } \\
\text { reported duty: PASPA ( } 4 \\
\text { members); Dang Wangi } \\
\text { (22 members); Ampang } \\
\text { (15 members); Cheras ( } 8 \\
\text { members). }\end{array}$ & $\begin{array}{l}\text { RQ Tender } \\
\text { (2 no); } \\
\text { Lorry Trucks } \\
\text { (4 nos); } \\
\text { Ambulance } \\
\text { (2 nos) }\end{array}$ & $\begin{array}{l}\text { RQ Tender } \\
\text { (2 no); } \\
\text { Lorry } \\
\text { Trucks } \\
\text { (2 nos); } \\
\text { Ambulance } \\
\text { (1 nos); } \\
\text { LRV (2 nos) }\end{array}$ & $\begin{array}{l}101 \\
(91)\end{array}$ & $\begin{array}{l}8 \\
(80)\end{array}$ & $\begin{array}{l}49 \\
(36)\end{array}$ & $\begin{array}{l}7 \\
(47)\end{array}$ \\
\hline & & $\begin{array}{l}\text { 2000 SAR activities } \\
\text { were suspended }\end{array}$ & $\begin{array}{l}\text { 2000 SAR activities were } \\
\text { suspended }\end{array}$ & - & - & - & - & - & - \\
\hline
\end{tabular}




\begin{tabular}{|c|c|c|c|c|c|c|c|c|c|}
\hline \multirow[t]{4}{*}{ 1993) } & $\begin{array}{l}5 \\
(\mathrm{Dec} \\
10, \\
2014)\end{array}$ & $\begin{array}{l}\text { O700 MCDF } \\
\text { Responder reported } \\
\text { duty: Dang Wangi (42 } \\
\text { members); Ampang } \\
\text { (31 members); Cheras } \\
\text { (11 members); Hulu } \\
\text { Langat (18 members) }\end{array}$ & $\begin{array}{l}\text { O700 MCDF Responder } \\
\text { reported duty: PASPA ( } 2 \\
\text { members); Dang Wangi } \\
\text { (28 members); Ampang } \\
\text { (13 members). }\end{array}$ & $\begin{array}{l}\text { RQ Tender } \\
\text { ( } 2 \text { no); } \\
\text { Lorry Trucks } \\
\text { (4 nos); } \\
\text { Ambulance } \\
\text { (2 nos); } \\
\text { LRV (2 nos) }\end{array}$ & $\begin{array}{l}\text { RQ Tender } \\
\text { (1 no); } \\
\text { Lorry } \\
\text { Trucks } \\
\text { (2 nos); } \\
\text { Ambulance } \\
\text { (1 nos); } \\
\text { LRV (2 nos) }\end{array}$ & $\begin{array}{l}102 \\
(92)\end{array}$ & $\begin{array}{l}10 \\
(100)\end{array}$ & $\begin{array}{l}43 \\
(31)\end{array}$ & $\begin{array}{l}6 \\
(40)\end{array}$ \\
\hline & & $\begin{array}{l}\text { ogoo use of an } \\
\text { excavator, bulldozer } \\
\text { and concrete breaker } \\
\text { machine }\end{array}$ & $\begin{array}{l}\text { 1000 Residents are } \\
\text { allowed to take personal } \\
\text { items }\end{array}$ & - & - & - & - & - & - \\
\hline & & $\begin{array}{l}\text { 1530 Found } 6 \text { death } \\
\text { body }\end{array}$ & \multirow[t]{2}{*}{$\begin{array}{l}2000 \text { All activities were } \\
\text { stop. }\end{array}$} & - & - & - & - & - & - \\
\hline & & $\begin{array}{l}2000 \text { SAR activities } \\
\text { were suspended }\end{array}$ & & - & - & - & - & - & - \\
\hline \multirow[t]{3}{*}{$\begin{array}{l}6 \\
(\text { Dec 6, } \\
\text { 1993) }\end{array}$} & & \multirow{2}{*}{$\begin{array}{l}\text { O700 MCDF } \\
\text { Responder reported } \\
\text { duty: Dang Wangi ( } 32 \\
\text { members); Ampang } \\
\text { (23 members); } \\
\text { Cheras ( } 8 \text { members); } \\
\text { Hulu Langat (19 } \\
\text { members) }\end{array}$} & & $\begin{array}{l}\text { RQ Tender } \\
\text { ( } 2 \text { no); } \\
\text { Lorry Trucks } \\
\text { (4 nos); } \\
\text { Ambulance } \\
\text { (2 nos); }\end{array}$ & - & $\begin{array}{l}82 \\
(74)\end{array}$ & $\begin{array}{l}10 \\
(100)\end{array}$ & & \\
\hline & & & & LRV (2 nos) & & & & & \\
\hline & & $\begin{array}{l}\text { 2000 SAR activities } \\
\text { were suspended }\end{array}$ & & - & - & - & - & & \\
\hline 7 & & O700 MCDF & & RQ Tender & - & 93 & 10 & & \\
\hline
\end{tabular}


ASM Science Journal, Volume 12, 2019

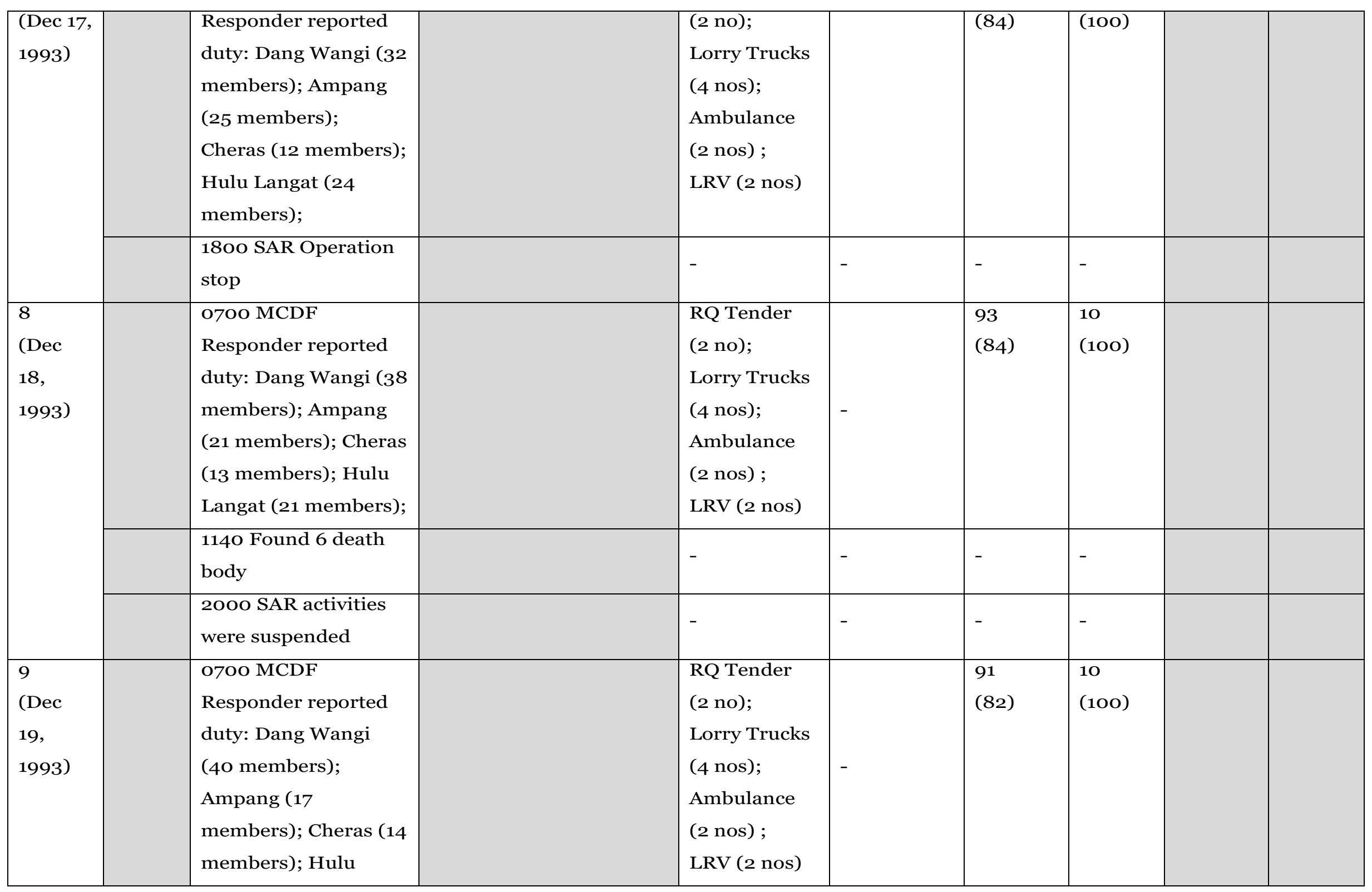


ASM Science Journal, Volume 12, 2019

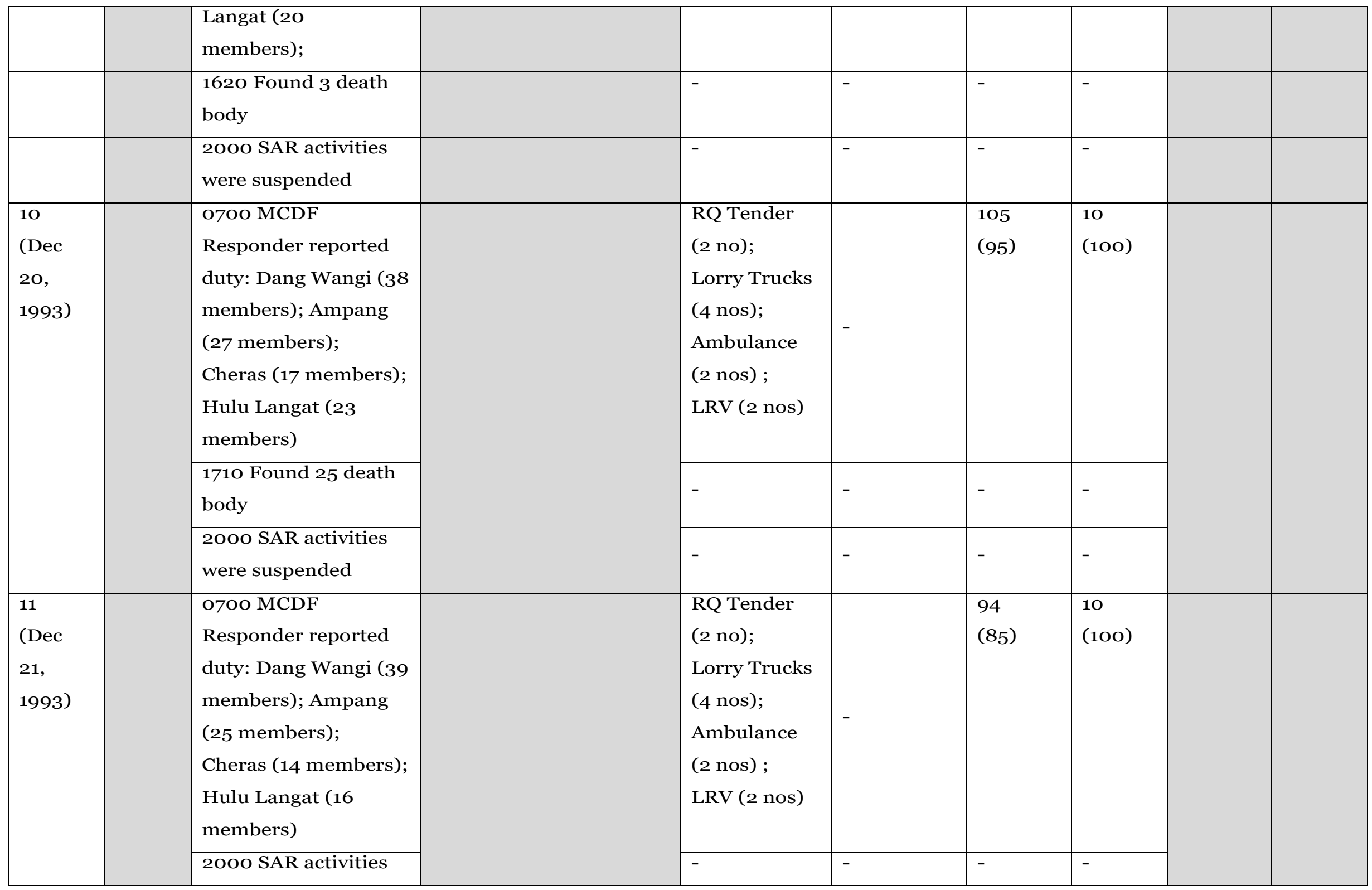


ASM Science Journal, Volume 12, 2019

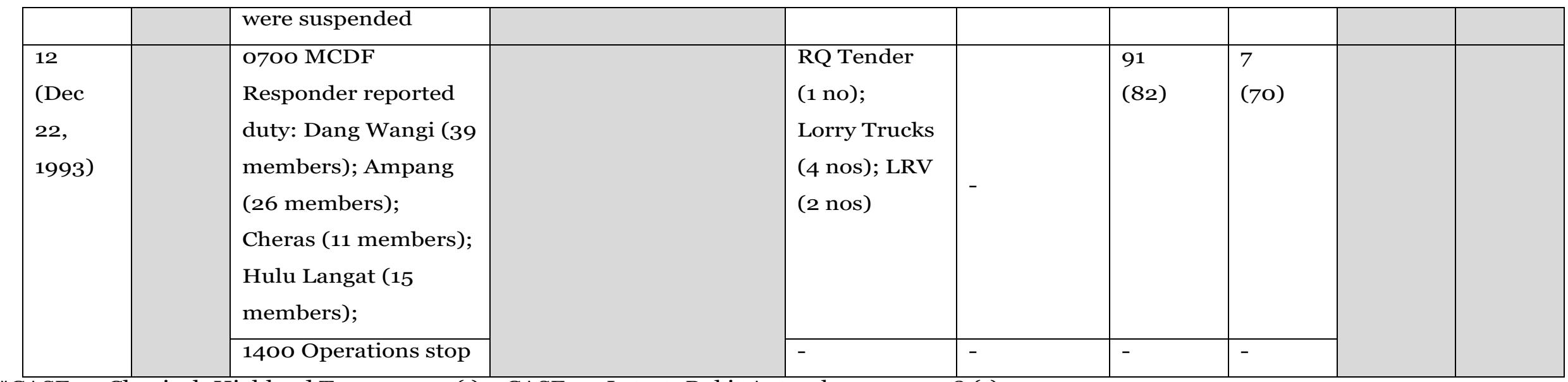

*CASE 1 - Classical: Highland Tower, 1993 (1); CASE 2 - Latest: Bukit Antarabangsa, 2008 (2) 
The response indicates the time lag between Cases 1 and 2 (Figure 4). The maximum numbers of MCDF responder were $111\left(\sum \mathrm{HR}_{1}\right)$ for Case 1 on Day 3; and $137\left(\sum \mathrm{HR}_{2}\right)$ for Case 2 on Day 2. Meanwhile the maximum number of MCDF equipment was 10 ( $\left.\sum \mathrm{E}_{1}\right)$ : on Day 5; and 15 ( $\left.\sum \mathrm{E} 2\right)$ : on Day 3 for each case, respectively. It means that 72 hours' response time for MCDF personals reached their maximum numbers for Case 1, while only 48 hours response time for Case 2. Deployment of response time for $\mathrm{MCDF}$ equipment was 120 hours and 72 hours for each case respectively. This result shows the need for some improvement of response time for MCDF during landslide disaster. It clearly showed a decrease response time by $34 \%$ for deployment of personals and $41 \%$ for deployment of equipment.

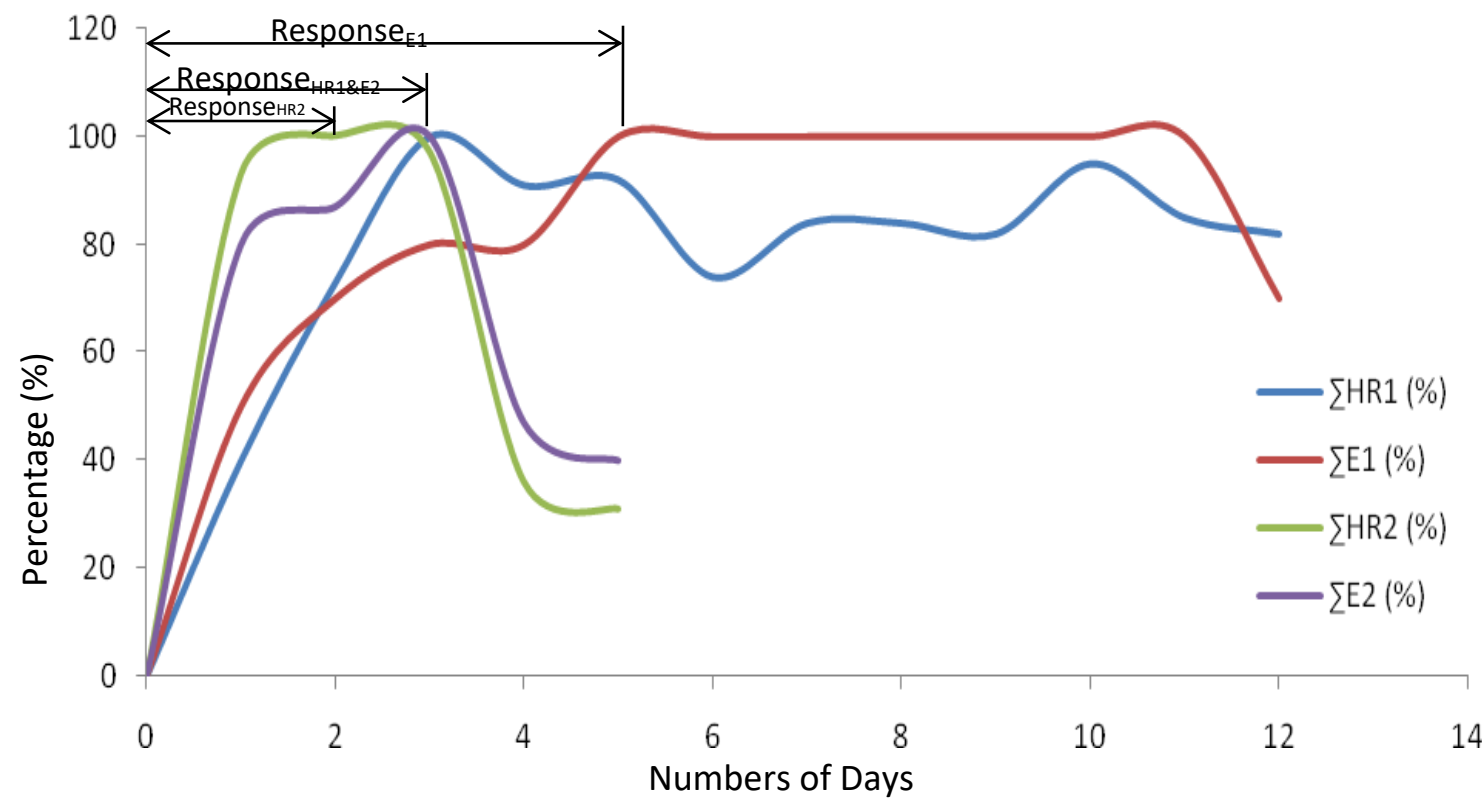

Figure 4. Deployments of MCDF Personals and Equipment

Following the Highland Tower incident in 1993, MCDF management has developed and mobilised their personnel to form an emergency hotline to facilitate the delivery of emergency and disaster information to take appropriate action quickly and efficiently. Later, on May 20, 1995, Emergency Hotline 991 was launched as a sign of MCDF commitment in providing 24-hour emergency assistance to public. The main objectives are to provide civil protection to the people; to protect and preserve the property and the environment, and to improve their standard of living with harmony and social of the people.

Emergency Hotline 991 was first launched in Kuala Lumpur as the onset of emergency and rescue services who work 24 hours - then followed by Penang, Ipoh, Johor Bahru and Kuching. Since then, Emergency Hotline 991 service-oriented of emergency response speed has served more thorough in the case of disasters, accidents and emergencies throughout the country. Asset additions and member recruitment expansion have been increasing since the launch of the Emergency Hotline 991. By 2000, Emergency Hotline 991 that operates 24 hours a day has fully operated in all 14 states offices and six district offices as a front based for MCDF services. It proves a strong commitment to the delivery services of MCDF close to the people.

Starting October 1, 2007, Emergency Hotline 
999 was introduced to the Malaysian community to combine all the emergency numbers 991 (MCDF), 994 (FRD) and 999 (Police and Hospital) into a single emergency number involving agency of the Malaysia Civil Defence Department (MCDF), Royal Malaysian Police (RMP - Police), Ministry of Health Malaysia (MOH - Hospital) and the Fire and Rescue Department (FRD) for integrating data management, the number of agency force and the use of an integrated system to enhance the delivery of emergency services among agencies on the procedures with a standardized service to coincide with the government through the motto "One Malaysia, One Number". Two MCDF call centre for the Malaysian Emergency Response System (MERS) was fully operated in 2008, and in 2012 the system was expanded in the state of Negeri Sembilan, Melaka, Johor, Pahang, Penang, Sabah and Sarawak. This system was able to identify all calls made since the caller's number appeared and retained for record. It helps avoid dropouts when an emergency call is made while monitoring the prank calls. Each prank call can be fined up to RM50,000.00 or imprisonment for one year or both, under Section 233 of the Communications and Multimedia Act 1998.

Meanwhile, Civil Defence Special Forces (Pasukan Khas Pertahanan Awam, PASPA) was officially launched on August 15, 2008, by Deputy Home Minister. PASPA was established to create a team of specialists in search and rescue operations. This team has special expertise such as urban search and rescue, combat water rescue, HAZMAT, water rescue, advanced rescue diver and more. PASPA special expertise is able to stand tall with rescuers from other agencies as Special Malaysia Disaster Assistance and Rescue Team (SMART) from NSC; and Special Tactical Operation \& Rescue Malaysia (STORM) from Fire \& Rescue Department. During the landslide at Bukit Antarabangsa on December 6, 2008,
PASPA was moved to the scene along with some special equipment such as search and rescue life detector, fibre optic camera and other advanced equipment. In relation to that, the proposed list of basic equipment, which may be used by rescuers as standard equipment during the landslide rescue operations, as shown in Table 3.

Table 3. Proposed Lists of Basic Equipments for Rescuer during Landslide Event

\begin{tabular}{|c|c|c|c|}
\hline No & Equipment & No & Equipment \\
\hline 1 & $\begin{array}{l}\text { Generator Set } \\
\text { (c/w engine oil } \\
\text { and lubricating } \\
\text { oil) }\end{array}$ & 8 & $\begin{array}{c}\text { Fiber Optic } \\
\text { Search \& Rescue } \\
\text { Camera }\end{array}$ \\
\hline 2 & Tent & 9 & $\begin{array}{c}\text { Powersaw / } \\
\text { Chainsaw }\end{array}$ \\
\hline 3 & Rope & 10 & Handsaw \\
\hline 4 & Stretcher & 11 & Portable Pump \\
\hline 5 & Medications & 12 & $\begin{array}{c}\text { DELSAR Live } \\
\text { Detector }\end{array}$ \\
\hline 6 & $\begin{array}{c}\text { Jack/air lifting } \\
\text { bag }\end{array}$ & 13 & $\begin{array}{c}\text { Mobile Lighting } \\
\text { Balloon }\end{array}$ \\
\hline 7 & Shovel & 14 & Hoe \\
\hline
\end{tabular}

MCDF has also prepared a guide for the special emergency rations to the rescue team in the early stages of disaster or emergency. This is a measure of care for the welfare of emergency officials. Emergency rations can hold up to 24 hours as an early stage of disaster before assistance from MCDF food preparation team reached the scene. There are three sets of menu options for emergency rations provided by MCDF to their rescuers for the supply of 24 hours/person during the operation, as shown in Table 4 . 
Table 4. Proposed MCDF Emergency Rations Pack

\begin{tabular}{|c|c|c|c|}
\hline \multirow{2}{*}{ No } & \multicolumn{3}{|c|}{ Emergency Rations Pack (24hour/person per pack) } \\
\hline & Set Alpha & Set Bravo & Set Charlie \\
\hline \multicolumn{4}{|c|}{ A. Main Menu } \\
\hline 1 & 140g Sweet \& Sour Fish & 140g Ayam Kurma & $\begin{array}{lll}\text { 140g Ayam Masak } \\
\text { Merah }\end{array}$ \\
\hline 2 & 140g Chicken Curry & 140g Beef Rendang & 140g Fish Curry \\
\hline 3 & $\begin{array}{l}\text { 140g Mixed Vegetables } \\
\text { with Soun }\end{array}$ & $\begin{array}{l}\text { 140g Mixed Vegetables } \\
\text { with Soun }\end{array}$ & $\begin{array}{l}\text { 140g Mixed Vegetables } \\
\text { with Soun }\end{array}$ \\
\hline 4 & 140g Mix Salads & 140g Pajeri Nenas & 140g Kacang Sepat Dhal \\
\hline 5 & 140g Cereal & $\begin{array}{l}\text { 140g Bubur Pulut } \\
\text { Hitam }\end{array}$ & $\begin{array}{lll}140 g & \text { Bubur Kacang } \\
\text { Merah } & \end{array}$ \\
\hline 6 & 40og Instant White Rice & 40og Instant White Rice & 40og Instant White Rice \\
\hline \multicolumn{4}{|c|}{ B. Additional Items (Same for each Set) } \\
\hline 7 & 4g Coffee & & \\
\hline 8 & $4 \mathrm{~g}$ Tea & & \\
\hline 9 & 56g Sugar & & \\
\hline 10 & 12g Creamer & & \\
\hline 11 & $3 g$ Salt & & \\
\hline 12 & 20g Isotonic Drink & & \\
\hline 13 & 500ml Drinking Water & & \\
\hline 14 & 8og Biscuit & & \\
\hline 15 & 40g Pineapples Jam & & \\
\hline 16 & 1 box of Match & & \\
\hline
\end{tabular}

* Selection of emergency rations set depends on operational management.

This positive development shows the efficiency of the services provided by MCDF due to handling the emergencies events in providing the best service to the people. The continuous improvement process is expected by integrated scientific research for improving the quality of MCDF services delivery and increasing the level of competence of its force members. Besides that, the welfare of its members is reserved by the knowledge supplied of rescue skills for improving their competence, willingness of the management to provide the latest and modern rescue equipment and providing food needs in an emergency case. This study also demonstrates the efficiency of the services provided by MCDF for handling the emergencies and providing the best services to the people in a changing environment.

\section{CONCLUSION AND RECOMMENDATION}

Landslides are known as a fatal disaster and caused the highest number of human losses in Malaysia. Therefore, the response phase is very critical and leading to this study. Given the complexity of landslide processes, activities and impacts, either involving different landslide types and materials, e.g. soil, rock, debris, and environment, e.g. urban setting, suburban, rural, mountainous or tectonically active region made the high demand of responses and required some flexibility. Malaysia landslides' statistics have 
shown that a well rehearses ERP and the right decision at the 'initial stage' of an emergency can reduce its impact and prevent substantial damages and losses. Many elements of an ERP are common to all circumstances, and these elements, in particular, should be known and practised by all. Data on specialised equipment and organisations must be updated. It is a valuable aid for disaster planning and communication.

When emergencies occur, the minimisation of loss and damage of people, property and environment can be achieved through the proper implementation of an appropriate standard SOP or ERP. This situation is shown by results of a comparison of two cases of landslides previously addressed by MCDF. It greatly enhances the following response activities: (i) save lives and prevent injuries; (ii) contain and minimise damage to property; (iii) effective command and control; (iv) fast and systematic response; (v) quick return to normalcy; and (vi) it is statutory requirement. Disaster sites are not training ground for rescuers, but it always a good lesson learned for better actions soon.

Moreover, MCDF highlighted PASPA as one of the main rescue teams in any SAR operations such as landslides, building collapses and other. With the expertise of this team, it improves the efficiency and effectiveness of ERP with other agencies. PASPA has specific exposure-related training and operations both locally and abroad and provided with the latest high-tech operations equipment and state-of-the-art technology. MCDF is also able to increase competence of its members; the use of latest and modern emergency equipment and systems; and developing infrastructure for better future. With the concept of ' $M C D F$ near the hearts of the people' as driven the Civil Defence services, MCDF can enhance the contribution to society.

Some characteristics of human response to a disaster area as follows (Ehrenreich, 2001):
Denial and inactivity - People normally ignore the possibility of a disaster such as a landslide. When it strikes, denial and disbelief will result as in 'this cannot be happening to me';

ii) Confusion - In the immediate aftermath of the disaster there is confusion and growing awareness of the resulting death, damage and injury;

iii) Anger and irritability - Survivors become irrationally angry and will ventilate their anger on rescue workers, medical staff and authorities;

iv) Dependency - Dependency and the need for comfort; victims want to be looked after, to be cared for whether through being given a blanket, a cup of tea or a similar item of comfort; apathy and withdrawn; and some victims become withdrawn and apathetic.

Therefore, training, drills, exercises and preparation can lessen the psychological effect of disasters on people. Liaison before, during and after the incident must take place. Otherwise it may be competing and confusing interests which will lessen the effectiveness of the operations. The involvement of the local community consisting residents and community leaders in all activities regarding the community preparedness is important to make sure the awareness and readiness during landslide (JPAM, 2015). It is proven that community based approach, where the local community is taken as the primary focus of attention in disaster reduction. This process has provided an opportunity for tapping traditional organisational structures and mechanisms (including formal and informal appointed community leaders) and capacity building activities with the community disaster committees and volunteers. Soon, a comprehensive disaster emergency response plan should be developed depending on the recent cases and reports. It is also taken into account the community ownership of such disaster plans, 
which facilitates the review and updating process of the plans with the local knowledge and community empowerment.

\section{REFERENCES}

[1] Bailey, ED \& T, Sweeney 2003, 'Considerations in Establishing Emergency Medical Services Response Time Goals', Prehospital Emergency Care, vol. 7, no. 3, pp. 397-399.

[2] Basu, R, R, Aggarwal, \& A, Jana 2017, 'An Integrated Framework for Allocation of New Emergency Response Facilities in Developing Nations', Process Integration and Optimization for Sustainability, vol. 1, no. 2, pp. 121-134.

[3] Blackwell, TH \& JS Kaufman 2002, 'Response Time Effectiveness: Comparison of Response Time and Survival in an Urban Emergency Medical Services System', Academic Emergency Medicine, vol. 9, no. 4, pp. 288-295.

[4] Desa, M \& J Niemczynowicz 1996, 'Spatial variability of rainfall in Kuala Lumpur, Malaysia: long and short term characteristics', Hydrological Sciences Journal, vol. 41, no. 3, pp. 345-362.

[5] Ehrenreich, JH 2001, Coping with disasters. A guide book to psychosocial intervention, Centre for psychology and society, New York, pp. 35-42.

[6] Faisal, H 2000, 'Unsaturated tropical residual soils and rainfall induced slope failures in Malaysia. in Unsaturated soils for Asia', in Proceedings of the Asian Conference on Unsaturated Soils, 18-19 May 2000, Singapore, AA Balkema.

[7] Huat, LT, F, Ali, and AS, Ibrahim 2012, 'An investigation on one of the rainfall-induced landslides in Malaysia', Electronic Journal of Geotechnical Engineering, vol. 17, pp. 435-449.

[8] Jaapar, A 2006, A Framework of a National Slope Safety System for Malaysia, University of Hong Kong.

[9] JPAM 2013, Laporan Pengoperasian Angkatan Pertahanan Awam Malaysia 2012, Jabatan Pertahanan Awam Malaysia (JPAM).

[10] JPAM 2012, Laporan Pengoperasian Angkatan Pertahanan Awam Malaysia Tahun 2011, Jabatan Pertahanan Awam Malaysia (JPAM).

[11] JPAM 2015, Panduan Kecemasan dan Pengurusan Bencana, Jabatan Pertahanan Awam Malaysia (JPAM).

[12] JPAM 2014, Pelan Strategik Angkatan Pertahanan Awam Malaysia 2015-2020, Jabatan Pertahanan Awam Malaysia (JPAM).

[13] Lee, ML, et al. 2014, 'Rainfall-induced landslides in Hulu Kelang area, Malaysia', Natural Hazards, vol. 70, no. 1, pp. 353-375.

[14] Mariappan, S, et al. 2011, Remedial Measures Adopted for Slope Failure at Bukit Antarabangsa, Malaysia, Enecal Consultants Sdn Bhd, Jabatan Kerja Raya, Mohd Asbi \& Associates, Kuala Lumpur, Malaysia.

[15] McCoy, CE, et al. 2013, 'Emergency Medical Services Out-of-Hospital Scene and Transport Times and Their Association With Mortality in Trauma Patients Presenting to an Urban Level I 
Trauma Center', Annals of Emergency Medicine, vol. 61, no. 2, pp. 167-174.

[16] METMalaysia 2017, Malaysia's Climate, Malaysian Meteorological Department (MetMalaysia).

[17] PWD 2017, Revised National Slope Master Plan 2017-2023, Jabatan Kerja Raya Malaysia.

[18] Saadatkhah, N, A, Kassim, \& LM Lee 2015, 'Susceptibility assessment of shallow landslides in Hulu Kelang area, Kuala Lumpur, Malaysia using analytical hierarchy process and frequency ratio', Geotechnical and Geological Engineering, vol. 33, no. 1 , pp. $43-57$.

[19] Samah, FA 2007, 'Landslides in the Hillside Development in the Hulu Klang', in Klang Valley Post-Graduate Seminar Semester, vol. 2.

[20] Sardi, MF 2012, Kajian Pencapaian Prestasi Pasukan Kecemasan JPAM Terhadap Penetapan Petunjuk Prestasi Utama (KPI) Ambulance Emergency Response Time (AERT), Institut Tadbir Awam (INTAN) Bukit Kiara.

[21] Sew, IDGS \& ITY Chin 2006, Landslides: Case Histories, Lessons Learned And Mitigation Measures, Landslide, Sinkhole, Structure Failure: MYTH or SCIENCE.

[22] Swaroop, M, et al. 2013, 'Pre-hospital transport times and survival for hypotensive patients with penetrating thoracic trauma', Journal of Emergencies, Trauma, and Shock, vol. 6, no. 1, pp. 16-20.

[23] Tijssen, JA, et al. 2015, 'Time on the scene and interventions are associated with improved survival in pediatric out-of-hospital cardiac arrest', Resuscitation, vol. 94(Supplement C), pp. 1-7.
[24] Wilde, ET 2013, 'Do emergency medical system response times matter for health outcomes?', Health Economics, vol. 22, no. 7, pp. 790-806. 